\title{
MEMOIRS
}

\section{EMILE MARCHAND}

Prof. Dr. Emile MARCHAND came into prominence in international actuarial circles in the period leading up to the Second World War. Political events had left their mark on international relations, and in such a situation it was natural that Switzerland should have been chosen as the host country for an International Congress (the twelfth) in 1940. Marchand, as Vice-President of the Swiss Actuarial Association, was entrusted with much of the work of preparation for the Congress. Fortunately, though the plans for meeting in Switzerland were abandoned due to the war, the papers had already been collected and were later published. Marchand was already well known to many members of the Institute by 1940 , and he was elected Corresponding Member in that year.

He was born on 13 February 1890 in La Chaux-de-Fonds, and his distinguished career is described in a memoir published in the Swiss Actuarial Bulletin. He obtained his doctorate at the technical university in Zurich at the age of 23, and in the same year entered the service of the well-known company, Schweizerische Lebens-versicherungs und Rentenanstalt, in which he spent the whole of his business career. He became Actuary in 1920 and was General Manager from 1947 to 1958 during which period the company celebrated its centenary. He was well known as a teacher of insurance mathematics at the technical university in Zurich, and was awarded the honorary title of Professor in 1940.

He was elected President of the Swiss Actuarial Association in 1946 and occupied that office until his retirement in 1958. He also represented Switzerland in the International Actuarial Association (then known as the 'Permanent Committee') from 1947 to 1960 as Vice-President and thus kept in constant touch with his colleagues abroad. He attended the 1968 Congress in Munich and followed the proceedings with great interest.

Though somewhat reserved in his disposition, Marchand was well liked by his many friends in this country and earned the warn regard of actuaries brought into close contact with his work. He died on 21 April 1971.

J. HAMILTON-JONES

\section{ARTHUR GRIBBLE SIMONS}

ARthur Simons died very suddenly on 10 August 1971 at a time when all his friends were confident that he had fully recovered from a minor heart attack a year earlier. He was 68 . At school-K.C.S., Wimbledon-he was an able mathematician and, surprisingly perhaps in view of his physique, a fast bowler, his interest in cricket continuing throughout his life. Mathematics he regarded as a tool; for intellectual enjoyment he preferred chess and bridge, and this preference is enlightening for, though he could apply cold logic when it was needed, for example in negotiation, at which he was a past master, his mind was essentially intuitivehe had flair. On more than one occasion when asked by a colleague why he had made a certain decision, he replied 'I don't know-I'll tell you tomorrow'. He usually did, and the decision 'stood up'.

Leaving school, he joined the London \& Lancashire under the mistaken impression, so he said, that every insurance company employed actuaries. The story, perhaps apocryphal, though told by himself, is that he failed that Company's entrance examination in arithmetic because he omitted to show his 'working'-hence his interpretation of the initials F.I.A. as 'Failed in Arithmetic'. Whatever the truth of the matter, he soon found that the Motor Department was not his milieu, and in 1920 transferred to the Eagle Star \& British Dominions as it then was, first to the Investment Department and shortly afterwards to the Life Department. He became a Fellow of the Institute in 1931, but it was the advent of insured pension 